\title{
OORSAAKLIKHEID EN VRYHEID
}

(Lesing gehou voor die Suid-Afrikaanse Kongres vir Wysbegeerte, Stellenbosch, 1955).

Met die opskrif „Oorsaaklikheid en Vryheid" kan 'n mens jou op 'n groot aantal terreine begewe, in ons dae selfs op die terrein van die fisika. Ons wil egter hier 'n probleem van die etiek te berde bring en daarom is dit noodsaaklik dat ons die terme ,oorsaaklikheid" en ,vryheid" nader presieseer en die etiese probleem formuleer.

1. Oorsaaklikheid.

Dit blyk dat die mens in sy daaglikse lewe prakties op deterministiese standpunt staan. Met hierdie stelling bedoel ons dat die mens vir elke verandering 'n oorsaak vermoed of soek - 'n omstandigheid of omstandighede wat die verandering meebring, bepaal, veroorsaak of determineer. Die mens gee blyke dat hy die opvatting huldig dat niks sommer vanself gebeur nie. Al skryf hy die gebeurtenis ook toe aan die werking van gode, geeste of geheimsinnige kragte, dan bly die feit nog staan dat hy dit in elk geval aan iets of iemand toeskryf. Hy vermoed dat veranderinge of gebeurtenisse saamhang met voorafgaande omstandighede wat sodanige 
gebeurtenisse onvermydelik maak. Dit is dan die algemeen menslike oortuiging van die veroorsaking van gebeurtenisse of veranderinge, die mens se oorsaaklikheidsbesef.

By nadere ondersoek blyk dit dat die oorsaaklikheidseis, soos dit by die wetenskaplike dinkwerk van die kultuurmens geld, die volgende omvat:-

(a) Die algemene of formele kousaliteitsbeginsel: Vir elke verandering is daar 'n genoegsame oorsaak of oorsake - 'n voorafgaande omstandigheid of stel omstandighede wat die verandering meebring of bepaal en noodsaaklik of onvermydelik maak. Gegewe die oorsaak of oorsake, moet die werking intree.

(b) Die materiële kousale aksiomas, wat die verhouding van die voorafgaande oorsaak en daaropvolgende werking nader presieseer; die eise naamlik van ruimtelike en tydelike kontiguitteit, ekwivalensie van oorsaak en werking en die logiese afleibaarheid van die werking uit die oorsaak $\mathbf{1}$.

'n Wesenlike element van die kousaliteitsbeginsel wat ons hier moet beklemtoon, is die voorspelbaarheid van veranderinge. Indien die antesedente bekend is, kan elke verandering noukeurig voorspel word, omdat die werking noodsaaklikerwys op die oorsaak volg.

Hierdie kousaliteitsbeginsel is in besonder van belang in alle induktiewe werksaamheid en daarom is dit een van die (en miskien die vernaamste) fondamentstene van die natuurwetenskap. Elke gevolgtrekking uit ervaring, elke eksperiment, elke berekening van toekomstige situasies, alle voorspellinge en elke toepassing van verworwe kennis op die praktyk, d.w.s. in die tegniek, sou onmoontlik word wanneer die kousaliteitsbeginsel nie meer geld nie.

Die feit dat die kousaliteitsbeginsel in ons praktiese wetenskaplike werk van soveel belang is, laat ons vermoed dat dit op die een of ander wyse gefundeer kan word, maar dit is nog nie die fundering self nie. Die sterkste poging tot fundering is dié van Im. Kant. Hume het Kant uit sy "dogmatiese sluimer" gewek deur aan te toon dat die oorsaaklikheidsbesef nie empiries gefundeer kan wees nie. Teenoor Hume se skeptisisme gaan Kant dan uit ran die realiteit van die gegewens van die natuurwetenskap, waarin die oordele gegrond op die kousaliteitsbeginsel vir hom sintetiese oordele a priori is, d.w.s. oordele wat 'n ervaring-oorskrydende element bevat. Om hierdie ervaring-oorskrydende elemente te verklaar, gaan hy uit van die standpunt dat al wat aan ons gegewe is, 'n chaotiese massa verskynsels is wat as prikkels op ons inwerk. Die ordening van hierdie chaos is 'n subjektiewe bydrae van die menslike gees, naamlik die aanskouingsvorme ruimte en tyd en die twaalftal kategoriëe waarvan die

Opmerkings:

1) G. Heymans, Die Gesetze und Elemente des uissenschaftlichen Denkens, 4. Aufl., Johann Ambrosius Bart, Leipzig 1923, p. 304-330. 
kategorie oorsaaklikheid een is. Die „transzendentale Einbildungskraft” is die vermoë van die menslike gees wat dan bepaalde gegewens by bepaalde kategorië onderbring sodat ons in 'n besondere geval kan sê: $A$ is die oorsaak van B. Die algemene geldigheid van so 'n uitspraak berus op die feit dat die aanskouingsvorme en kategorië 'n deel van die „Bewustztsein überhaupt", die algemeen menslike geestelike toerusting uitmaak.

Sir William Hamilton, nagevolg deur Heymans, soek die verklaring in 'n ander rigting: ,When we are aware of something which begins to be, we are, by the necessity of our intelligence, constrained to believe that it has a cause. But what does the expression, that it has a caust, signify? If we analyse our thought, we shall find, that it simply means, that as we cannot conceive any new existence to commence, therefore, all that now is seen to arise under a new appearance had previously an existence under a prior form. We are utterly unable to realise in thought the possibility of the complement of existence being either increased or diminished. We are unable, on the one hand, to conceive nothing becoming something or, on the other, something becoming nothing."' 2 Hierdie oortuiging van die onmoontlikheid van vergaan en ontstaan is 'n ,,vera causa", ' $n$ eis van die menslike denke wat ons in die filosofie van die mensheid van sy begin tot vandag toe sien. Hiervandaan uit formuleer Heymans dan: „Ursache nennen wir die zu einer wahrgenommenen neuen Erscheinung hinzupostulierten, derselben vorhergehenden wirklichen Zustände und Prozesse als ihre gleichmäszige Fortsetzung ergeben". ${ }^{3}$ Die basis van hierdie beskouing is dat dit ' $n$ fundamentele oortuiging van die menslike gees is dat niks uit niks kan ontstaan of iets tot niet kan gaan nie; dat m.a.w. 'n volgende fase van 'n bepaalde werklikheid nie meer of minder werklikheidselemente as die voorafgaande fase kan bevat nie, dus dat die eintlike of substansiële werklikheid onveranderlik is. - Of ons hierdie verklaring nie weer verder kan terugroer na die formele denkwet van identiteit nie, is 'n saak waaroor die kenteoretici maar moet besluit. Waarop ons die aandag hier wil vestig, is dat die Kantiaanse sowel as die Hamiltonse verklaring in die rigting gaan dat die verklaring vir die kousaliteitseis subjektief in die gesteldheid van die menslike gees gesoek moet word.

\section{Vryheid.}

Net so seer 'n deel van die menslike bestaan en wat die praktiese handel en wandel van die mens betref net so algemeen as die oorsaaklikheidsbesef is die feit dat mense mekaar bepaalde gedragswyses toereken; ons reken toe ten goede of ten kwade, ons neem kwalik en verskoon, ons beloon en bestraf. Wanneer ons oor hierdie feit nadink, blyk dit dat ons

2) Sir Wildiam Hamilton, Lectutes II, p. 377, aangehaal in Heymans, Gesetze u. Elemente, p. 350 .

`) Gesetze u. Elemente, p. 357. 
iemand bepaalde gedragswyses toereken op grond daarvan dat ons die persoon verantwoordelik vir sy gedragswyse beskou. Verder: ons kan hom alleen verantwoordelik hou vir sy gedragswyse indien ons oortuig is dat hy self so optree, m.a.w. dat hy self beslis het of hy so gaan optree of nie. By ons toerekening veronderstel ons dus by die beoordeelde persoon vryheid, waarmee ons bedoel dat die persoon self kies, self sy handeling bepaal volgens wat vir hom tussen die verskillende moontlikhede en in die gegewe situasie die beste, aangenaamste of voordeligste skyn te wees.

Hierdie vrye handeling kan ons ook 'n wilshandeling noem, waarmee ons dan te kenne gee dat die persoon se eie wil in sy optrede geld.

So 'n vrye handeling beteken verder nie 'n handeling wat ordeloos of wetteloos geskied nie; dit kan v ry wees en nogtans volgens 'n bepaalde orde, prinsipe of wet geskied en selfs in gehoorsaamheid aan so 'n wet plaasvind. Die vereiste is hier egter dat die handelende persoon hierdie wet vir homself stel, minstens dat hy hierdie wet deur eie keuse aanvaar as sy wet waarvolgens hy wil handel. In hierdie terme gestel, kan ons dan die term outonomie as sinoniem met wilsvryheid bcskou. Die vry mens is die outonome mens en omgekeerd.

Negatief kan ons dit so stel: vryheid beteken nie absolute vryheid nie; die mens se vryheid word vanselfsprekend bepaal en beperk deur allerhande grense, b.v. die fisiese grense wat onoorkombaar is en wat gestel word deurdat ons wesens van 'n bepaalde aard van vlees en bloed is. Binne hierdie grense beteken vryheid dan die vermoë en die geleentheid om self tussen die verskillende moontlikhede te beslis en nie deur 'n vreemde mag of magte in ' $n$ bepaalde rigting gedwing te word nie.

Nie alleen is dit noodsaaklik dat ons nie deur vreemde magte buite onsself (b.v. die bevel van 'n offisier aan 'n soldaat) gedwing moet word nie, maar ons moet ook nie deur magte binne onsself gedwing word nie. Voorbeeld van sulke magte sou 'n gebrekkige verstand, onwillekeurige en outomatiese bewegings soos die stuiptrekkings van 'n epileptikus, 'n oorweldigende emosionele uitbarsting en so meer wees. Positief gestel: wanneer ons 'n persoon sy handelinge toereken, gaan ons van die veronderstelling af uit dat ons met 'n normale mens onder normale omstandighede te doen het, m.a.w. 'n mens wat die emosionelt selfbehter en die verstandelike helderheid het om die bepaalde moontlikhede waarvoor hy staan, te begryp; die implikasies, gevolge en aard van die moontlike handelinge te verstaan; en die sedelike besef te hê dat 'n bepaalde handeling sedelik goed- of afkeurenswaardig is en in watter mate dit sodanig is. In dieselfds mate as waarin aan hierdie vereistes nie voldoen word nie, is die persoon nie vry nie en dus nie toerekenbaar nie. Dit is die geval b.v. by kinders, idiote, kranksinniges en so meer.

\section{Die etiese Probleem.}

Die probleem vir die etikus ontstaan nou wanneer ons die oortuiging 
van universele veroorsaking van veranderinge met die implikasies daarvan probeer rym met die feit van toerekening saam met die veronderstelling waarop dit blyk te rus, nl. die oortuiging van die mens se $\mathrm{v}$ ryheid. Dit skep 'n antinomie. Ons word geplaas voor twee gelyklik onbetwyfelbare maar oënskynlik onderling teenstrydig sekerhede: enersyds die sekerheid van die kousaliteitsbeginsel, dat niks sonder oorsaak geskied, dat al wat gebeur dus oorsaaklik bepaal en dus noodsaaklik is; en andersyds die sekerheid dat alle sedelike toerekening en verantwoordelikheid, ten goede sowel as ten kwade, alle skuld en verdienste berus op die veronderstelling van vryheid, wat ontbreek wanneer 'n mens op watter wyse ook al in sy doen en late gedwing of genoodsaak word. ${ }^{4}$

Wat 'n mens wil en doen, is meteens 'n verandering wat hy beoog en bewerkstellig. Indien sodanige handeling bepaal word deur voorafgaande omstandighede, onvermydelik of noodsaaklik is, watter betekenis het toerekening en watter status het die mens se veronderstelde vryheid dan? Omgekeerd: Indien die mens se veronderstelde vryheid beteken dat 'n mens se handeling nie genoodsaak word deur oorsake nit, hoe kan ons dan op sinvolle wyse dink oor die soort veranderinge wat wilshandelinge genoem word? Sonder oorsaaklikheid kan daar geen wetenskaplike denke, sonder vryheid geen verantwoordelike bestaan met sedelikheid en reg wees nie.

\section{Pogings tot Oplossing.}

(a) Die eenvoudigste oplossing van die probleem is te vinde waar een of ander kant van die antinomie geloën word. Voorbeelde hiefvan is algemeen bekend, veral die standpunt van die meganistiese materialisme wat op die natuurwetenskap gebou is en in die 19de eeu sy hoogtepunt bereik. Hierdie uiterste loëning van alle vryheid, waar alle sedelikhtid 'n hersenskim word, is egter nooit deur meer as net 'n betreklike klein groєpie voorgestaan nie en in die etiek was dit nooit van werklike belang nie. In 'n afgewaterde vorm het dit egter 'n baie belangrike rol gespeel, waarop ons later weer sal terugkom.

Oorsaaklikheid as 'n algemeen geldige vooronderstelling het veral in swang gekom saam met die opkoms van die natuurwetenskap aan die begin van die moderne tyd. Dit is dikwels van etiese en godsdienstige kant bestry, maar het van krag tot krag gegaan totdat dit in die 19de eeu prakties algemeen aanvaar is. In ons eie tyd het ons 'n besondere interessante loëning van hierdie determinisme en wel vanuit die fisika self, in besonder vanuit die mikrofisika. Die begrip toeval moes in die fisika ingevoer word sodra 'n atomistiese struktuur van die stof aangeneem word. Die aanvaarding van die atomistiese struktuur van die stof het dit noodsaaklik

4) L. Polak in: W. J. Aalders e.a., Eerste Interfacultaire Leergang: Causaliteit en Wilstrijheid, Groningen 1936, p. 7. 
gemaak om die atoom en sy bewegings presies te ken indien ons presiese kennis van die stof wou hê. Die werk van Boltzmann teen die end van die vorige eeu, Planck aan die begin van ons eeu en andere het aangetoon dat ons geen volledige kennis van die atoombeweginge en wat daarmee saamhang, het nie. Ons kan daarom sekere reëls aangee, maar onveranderlike wette wat geen uitsondering toelaat nie, kan ons nie formuleer nie. Ons moet daarom in al ons berekeninge alleen met waarskynlikheidsreëls werk en vir die toeval 'n plek inruim - Prinsipieel het dit nog geen verandering aan die kousaliteitsbeginsel gemaak nie. Oorsaaklikheid in die fisika impliseer afleibaarheid, berekenbaarheid en voorspelbaarheid. Maar om 'n werking te kan aflei, bereken of voorspel, veronderstel dat ons die antesedente ken; waar die antesedente onbekend is, kan dit net nie gedoen word nie. Dit doen geen afbreuk aan die gedagte van oorsaaklikheid nie, maar toon alleen ons gebrekkige kennis.

Die werk van Einstein, die Broglie, Schrödinger, Bohr, Heisenberg en andere het egter 'n wesenlike verandering gebring. Ons wil op hulle werk nie ingaan nie, maar net konstateer dat (wat ons probleem betref), diebelangrikste aspek van hulle werk die feit is dat hulle die ou determinisjtiese standpunt moes verlaat en op 'n indeterministiese grondslag werk. Heisenberg met sy onsekerheidsrelasie skyn selfs vir ons prinsipiële grense van ons kenmoontlikhede aan te dui.

Op grond hiervan is daar mense wat meen dat die probleem wat ons hierbo gestel het, opgelos is. Die sterkste eis vir die determinisme is nog altyd vanuit die natuurwetenskaplike wêreld gestel en indien die natuurwetenskap nou self hierdie determinisme laat vaar, verval die etiese probleem eintlik vanself. Ons het daarmee ' $n$ herhaling van wat ons reeds by Epicurus aantref, naamlik 'n waarborg van ons wilsvryheid deur 'n indeterministiese element in ons natuurfilosofie. Dit is wat Polok spottend noem: ,Ethiek bij de gratie der quantenmechanica!”5

Ons wil hierby net 'n paar aantekeninge maak:

(i) Indien die oorsaaklikheidsbeginsel (soos ons hierbo saam met Kant gestel het) 'n a prioriese denkeelment is, is dit onafhanklik van die ervaring, word dit nie uit die ervaring verkry nie maar ook nie deur die ervaring weerlê nie. Die standpunt van die moderne fisika maak daarom nog geen verskil aan die etiese probleem nie.

(ii) Die nuwe indeterminisme beteken glad nie dat die ou deter minisme weerlê of as foutief bewys is nie. So ver dit die fisika betref, sê dit alleen dat die meerdere gegewens tot ons beskikking nie meer met die hipotese van die determinisme bewerk kan word nie en wel met die indeterminisme as werkhipotese, waarmee die determinisme nie as verkeerd bewys is nie, maar eenvoudig agtergelaat is. Die argument dat hierdie toedrag van sake aan ons gebrekkige kennis gewyt moet word, dat wanneer

5) $I d \mathrm{~cm}$, p. $13 n$. 
ons kennis vollediger is, dit sal blyk dat ons maar weer op deterministiese grondslag staan, maak ook nie veel indruk op die moderne fisikus nie. Sy antwoord is eenvoudig: Dit mag so wees, maar so ver ons huidige kennis strek, werk die determinisme nie meer nie en die indeterminisme wel. In Max Born se woorde: "The new theory appears to be well founded on observation, but one may ask whether in the future, by development or refinement it may not be made deterministic again. As to this it must be said: it can be shown by rigorous mathematics that the accepted formal theory of quantum mechanics does not admit of any such extension. If anyone clings to the hope that determinism will ever return, he must hold the existing theory to be false in substance; it must be possible to disprove experimentally definite assertions of this theory. The determinist should therefore not protest but experiment." 6

(b) Die Oplossing van Im. Kant wat in wese deur talle ander nagevolg word, is te bekend om lank by stil te staan. Die wese van sy oplossing lê daarin dat oorsaaklikheid 'n kategorie van die menslike denke is; en dat hierdie kategorië alleen op die fenomenale wêreld van toepassing is en nie op die noumenale wêreld nie. So ver dit die mens as sedelike wese betref, is die mens in so verre hy en sy handelinge aan die fenomenale wêreld behoort, onderworpe aan 'n streng uitsonderingslose oorsaaklikheid soos enige proses in die anorganiese wêreld; die mens as Ding an sich val egter nie hieronder nie en is dit moontlik om vryheid te dink, al is dit nie moontlik om dit te bewys in dieselfde sin as wat ons 'n empiriese gegewene kan aantoon nie. Daarmee is die deur vir hom oop om vryheid te postuleer as een van die vernaamste pilare waarop hy sy hele etiek bou.

Ons wil hierop nie verder ingaan nie; die problematiek en die argumente pro en contra is te bekend. Ons wil egter op een sakie wys: by sommige het die neiging ontstaan om onder invloed van Kant se beskouinge o.a. die oorsaaklikheidsbeginsel te vervlugtig tot iets geheel subjektiefs; dit sou dan „,maar net" 'n manier wees waarop ons 'n chaotiese verskynselewêreld orden; die versweë veronderstelling is dat hierdie verskynselewêreld origens vir ons onkenbaar is en miskien heeltemal anders is as wat ons daarvan maak. In hoe verre Kant werklik vir hierdie beskouing verantwoordelik gehou kan word, laat ek daar. Ek kan egter nie anders as om op hierdie punt met die realisme en pragmatisme van die natuurwetenskap simpatie te hê nie: $\mathrm{Al}$ is oorsaaklikheid 'n denkwet en a priori, besit dit objektiewe geldigheid, werk dit in die natuur en kan dit eksperimenteel gedemonstreer word. In die woorde van Max Planck: ,Wenn es die Aufgabe der Wissenschaft ist, bei allem Geschenen in der Natur oder im menschlichen Leben nach gesetzlichen Zusammenhängen zu suchen, so ist, wie wohl jeder zugeben musz, eine unerläszliche Voraussetzung dabei, dasz ein solcher gesetzlicher Zusammenhang wirklich besteht, und dasz

8) MAx Born, Naturuissenschaften, 1929, aangehaal en vertaal deur Sir Arthur EddingTOs, New Pathuays in Science, Cambridge 1935, p. 72. 
er sich in deutliche Worte fassen läszt. In diesem Sinn sprechen wir auch von der Gültigkeit eines allgemeinen Kausalgesetzes und von der Determinierung sämtlicher Vorgänge in der natürlichen und in der geistigen Welt durch dieses Gesetz." " Wat ons probleem betref, lyk dit vir my weer na 'n ontvlugting van die probleem om 'n onderskeid te maak tussen die werklikheid en ons interpretasie van die werklikheid.

(c) Die oplossing wat waarskynlik die meeste tevredenheid gee, is wat die sterkste deur G. Heymans uitgewerk is en wat ons as voorbeeld neem, maar wat ons ook as 'n tipe kan beskou: 'n Analise van die sedelike oordeel toon dat die sedelike oordeel as voorwerp van beoordeling dié handelinge het wat ons as wilshandelinge kan beskou. Die wilshandeling toon op sy beurt weer die volgende momente:

(i) Voordat 'n handeling uitgevoer kan word, moes 'n mens eers daaraan gedink het. Ons moet dus 'n voorstelling van die handeling hê (motiefvoorstelling of motief). Hierdie voorstelling kan op verskillende maniere ontstaan, b.v. deur direkte waarneming van bepaalde omstandighede, deur assosiasie, ens.

(ii) Wanneer ons die handeling en verwagte resultate daarvan voorgestel het, vind 'n mindere of meerdere oorweging van die situasie, die handeling, die resultate en so meer plaas.

(iii) As die voorstelling van die handeling of sy resultate aanklank vind by ons karakter, begeer ons om die handeling te verwerklik. Die karakter ,läszt sich . . . bestimmen als die Gesammtheit der Neigungen ... in ihren gegenseitigen Stärkeverhältnissen." 8 Die neiging, in teenstelling tot die wens en begeerte wat bloot tydelik en verbygaande is, is 'n blywende aanleg van die mens. Alle mense het alle neiginge; die verskil tussen mense kom by die sterkteverhouding van die neiginge. As die neiging(e) waarby die voorstelling aanknoop, van oorwegende sterkte is, volg die volgende stap in die wilsproses. Indien nie, word die voorstelling verwerp.

(iv) Wanneer die voorstelling by die neiging(e) van oorwegende sterkte aanknoop, aanvaar ons die voorstelling as doel van die handeling. Hierdie aanvaarding van die voorstelling as doel van die handeling is die wesenskenmerk van die wil, maar is afhanklik van die karakter. $\mathrm{Na}$ 'n mindere of meerdere oorweging van die middele wat in die handeling aangewend moet word, volg die handeling. Noodsaaklik vir elke wilshandeling is dus motief en neiging.

Aan die oorsaaklikheidseis voldoen Heymans deur die beskouing dat geen wilshandeling oorsaakloos plaasvind nie. Elke handeling is die noodwendige resultaat van sy antesedent?, warrvan die situasie van die handelende parsoon, die motief en veral die karakter van die persoon die belangrikste is. Net so streng en uitsonderingsloos as wat die wet van oor-

7) Dr. Marx Planck, Vom Wesen der Willensfreiheit, Leipzig 1937, p. 5.

8) G. Hermaxs, Einfuhrung in die Ethik, Johann Ambrosius Barth, Leipzig 1923, p. 43. 
saaklikheid in die prosesse van die natuur geld, net so streng geld dit ook ten opsigte van die wilshandeling. Trouens, ons buitewêreld, wat aan ons gegewe is as 'n nimmereindigende stroom van afsonderlike ervaringe van gebeurtenisse en dinge, verbind ons onder die begrip van oorsaak en werking, maar om dit moontlik te maak is die mens verplig om die hipotese van $\mathrm{krag}$ aan te neem. Hierdie krag vorm die relasie tussen die verskillende dinge en daarin is die eienskappe van die dinge gegrond. Saam met die begrip krag is ook vir ons die begrip wet gegewe, wat die optrede van die krag formuleer. Dieselfde vind ons op psigiese gebied, waar die stroom innerlike gebeurtenisse verbind is deur oorsaak en werking en gegrond is in 'n psigiese $\mathrm{krag}$, wat ons as gelyksoortig met die krag in die natuur moet beskou. Net soos die natuurkrag is die psigiese krag onveranderlik en konstant. Gebeurtenisse, veranderinge, ontwikkeling ens. vooronderstel altyd die elementêre kragte, sowel op psigiese as op fisiese gebied. „Es darf also a priori vorausgesetzt werden, dasz auch die Erscheinungen des menschlichen Wollens sich auf elementare, constante Kräfte werden zurückführen lassen, dasz also ein Jeder bei vollständiger Selbsterkenntniss swischen Vorstellungen bestimmter Art und Strebungen von bestimmter Intensität einen festen, unveränderlichen Causalnexus würde nachweisen können." Hierdie „Causalnexus” is die sisteem van elementêrc kragte wat die diepstє wese van die mens vorm en wat ons neiginge noem. Die sisteem van elementêre kragte as 'n funksionele gehєel is die karakter. Die karakter is dan onveranderlik, 'n decl van die diepste realiteit en dit is die bepalende faktor van ons wilshandelinge.

Aan die eis van uryheid voldoen Heymans in sy beskouing deur die gedagte dat hierdie karakter wat ons wilshandelinge bepaal, die diepste wese van die mens is. Elke wilshandeling is dus vry, omdat die mens self daardie handeling bepaal. Dit is onvry wanneer iats anders as hierdie diepst $\epsilon$ wese van die mens die handeling veroorsaak. In 'n wilshandeling hestaan daar nie soiets dat ons iets doen wat ons nie regtig wou doen nie. Elke wilshandeling is die handeling wat ons die graagste wou doen, omdat dit die resultaat is van die sterkste neiging(e) in ons katakter; die gevoel wat ons soms het dat ons iets gedoen het of 'n lewe lei wat ons liewer nie sou wou doen nie, kom uit die feit dat ons ook waardering het vir die soort handelinge wat ons self nie uitvoer nie, dat ons m.a.w. ook die neiginge in hierdie rigting het. Hierdie neiginge is egter swakker as die ander en daarom doen ons die handeling wat ons doen. Dit beteken egter nie dat ons onvry is nie, maar vry, want dit is nog altyd ons eie neiging wat ons in 'n bepaalde rigting stuur.

Aan die voorwaardes vir sedelike keuring voldoen Heymans ook met hierdie teoric. Wanneer ons 'n toerekenbare persoon sedelik beoordeel,

-) G. Heymans, Zurechnung und Vergeltung, Gesammelte Kleinere Scgriften II, Martinus Nyhoff, Den Haag 1927, p. 487. 
mak ons 'n uitspraak oor hoedanig hierdie persoon in sedelike sin is: hy is sleg of hy is goed. Vir ons sedelike keuring is dit noodsaaklik dat ons die geleentheid sal hê om te wete te kom hoe hierdie persoon is. Omdat hy volgens sy eie diepste wese handel en ons daardie handeling na analogie van onsself kan verstaan, kan ons hom oordeel.

Hierop wil ons enkele opmerkings maak:

(i) Heymans is in 'n besondere mate konsekwent en tegelyk 'n etikus van besondere formaat. As ons ons tot die etiese probleemstelling beperk, kan ons nie anders as om met Heymans saam te stem nie.

(ii) Die vrae ontstaan egter sodra ons na die antropologiese en metafisiese probleme oorskakel. Die metafisika op die agtergrond van Heymans se etiek is sy Psigo-monisme. Die diepste realiteit is die "Weltgeist" of "All-Seele", waarvan die mens 'n individuasie is. Die goed en sleg wat ons in die individuele mens beoordeel, is per slot van rekening die goed en sleg wat in die diepste realiteit aanwesig is en in die mens te voorskyn tree. Net soos elke kousale reeks waaraan die mens geen deel het nie, prinsipieel oneindig is, is ook die kousale reeks waaruit die mens sc handeling bestaan, 'n reeks waar die individuele mens per slot van rekening 'n insident is, wat vloei vanuit die diepste werklikheid deur die mens heen. Heeltemal in lyn hiermee staan ook sy beskouing van die onveranderlikheid van die karakter: Die karakter moet vir hom onveranderlik wees, omdat dit 'n individuasie van die Alsiel is en daarom onafhanklik van die individu se eie aktiviteit. Heymans is heeltemal reg waar hy sê dat ons in die sedelike oordeel nie vra na die herkoms van die karakter nie, maar alleen die karakter wat te voorskyn tree, as goed of sleg beoordeel. Die konsekwensie van sy metafisika is egter 'n fatalisme en hoe 'n mens 'n metafisiese fatalisme met ' $n$ etiese vryheid tegelyk kan handhaaf, is vir my 'n geheim. Heymans se werk is vooruitgeloop, dikwels woordeliks, deur Ludwig Feuerbach, hoewel Heymans nooit na hom verwys nie. Feuerbach trek egter 'n konsekwensie wat Heymans weier om te trek: Feuerbach sê dat 'n mens so vry is soos die weerhaan wat deur die Noordelwind gewaai word om Noord te kyk en dan sê : ,Ek is vry, want ek kyk Noord omdat ek Noord wil kyk."

In sy Inleiding tot de Speciale Psychologie verlaat Heymans dan ook hierdie lyn volkome. ${ }^{10} \mathrm{Hy}$ behandel hier die herkoms van die karakter en onderskei (i) die aangebore karakter, wat bepaal word deur psigiese en liggaamlike erflikheid en huwelikseleksie; (ii) die verworde karakter, wat bepaal word deur die ontwikkelingsgang van die mens en omgewingsfaktore; en eindelik (iii) die selfgemaakte karakter, wat bepaal word deur die feit dat die indiwidu reeds vroeg in sy lewe 'n ideale voorstelling van homself vorm en probeer om homself so te maak. - Dit is lg. wat hier van belang is. Hierdie selfgemaakte karakter het alleen sin wanneer dit

19) G. Heymans, Inleiding tot de steciale Psychologie II, 2de druk, Haarlem 1932, p. 220 vv. 
moontlik is vir die individu om een deel van sy persoonlikheid teen die ander in te span. Selfs opvoeding, in so verre dit opvoeding en nie afrigting is nie, kan sonder hierdie inspanning van die individu teen homself nie plaasvind nie. Soiets is vir my alleen moontlik waar ons die mens as 'n prima causa kan beskou, of om dit in Hartmaan-Kantiaanse terme te stel: Die kousale reeks laat toe dat nuwe faktore in die reeks bygevoeg word maar nie weggeneem word nie; 'n „Plus en Determination" is moontlik maar nie 'n „Minus an Determination" nie. Die mens het die vermoë om 'n ekstra faktor in die kousale reeks te word en kan daarom 'n kousale reeks begin of die verloop van 'n reeks verander. Hoe ons dit ook al formuleer, ons kom nie daarby verby om aan te neem dat die mens daartoe in staat is om self te beslis en daarvolgens te handel nie.

Met hierdie formulering sal Heymans ten volle kan saamstem; ook hy beweer dat die mens beslis en daarvolgens handel; die vraag is egter of hierdie selfbeslissing gedetermineer is of nie. 'n Matafisiese determinasie soos ons by Heymans vind, kan ek nie aanvaar nie; alle vorme van $\mathrm{Al}$ siele en Wêreldgeeste is hoogs spekulatief en het met 'n Dullstroomse miswolk gemeenskaplik dat dit die werklikheid net bedek en verwring. Geen wilsbesluit vind egter daarenteen rede-loos plaas nie en is gegrond in bepaalde antesedente.

Hierdie gegrondheid is nou weer die probleem. Beteken dit, soos by Heymans, dat die beslissing kousaal gedetermineer is deur 'n vaste gegewenheid, naamlik ons neigings? Daar is een oorweging wat my hier versigtig stem: Wanneer een van hierdie neigings 'n oorweldigende sterk posisie inneem, b.v. in dic geval van 'n seksomaniak, het ons te doen met 'n geval van sedelike ontoerekenbaarheid of verminderde toerekenbaarheid, al kom in die optrede van die persoon alleen te voorskyn wat hy self is. Hoekom? Heymans antwoord: omdat daar in so 'n geval geen vryspel van motiewe is nie, wat weer beteken: geen ander neiging het ' $n$ kans om ins loed uit te oefen nie en die persoon word meganisties in een rigting gedwing. Hierop wil ek net vra: Is dit nie eerder'n geval dat die persoon sy selfbeheer kwyt is nie? Onder hierdie doodgewone woorde lê 'n hele boel opgesluit: die persoon het nie meer die geleentheid om die situasie, sy handeling en die gevolge daarvan te oorweeg en daarvolgens te beslis nie. Die konsekwentheid van 'n persoon se optrede, wat vir Heymans en baie andere ' $n$ bewys van kousaliteit is, hoef geensins ' $n$ kousaliteit van neiginge te wees nie, maar kan net so goed die uitvloeisel van 'n rangorde van waardevoorkeur wees. Die rangorde van waardevoorkeur bepaal die mens in sy optrede, is die grond vir sy beslissings, en daarom kan ons ook hier van determinering praat. Maar die determinering is heeltemal van 'n andere orde:

(i) Die waardes het geldigheid; dit spreek die individu sowel as die gemeenskap aan met die behoorlikheidseis; maar daar is geen noodwendigheid, geen noodsaaklike verloop van oorsaak en werking nie. Die 
moontlikheid, wat dikwels verwerklik word, is daar om hierdie anspraak van die waardes te ignoreer en in stryd daarmee op te tree; of presieser gestel: om waardes wat deur die gemeenskap hoog geskat word, ondergeskik te stel aan waardes wat vir die individu groter geldigheid het.

(ii) Die geldigheid van die waardes berus nie op die feit dat ons bepaalde neiginge het nie, maar op die feit dat die mens 'n sedelike wese is, m.a.w. kan onderskei tussen goed en kwaad en ontvangklik is vir die appél van die behoorlikheidseis. Hierdie , sweeping statement" is 'n probleem van die wysgerige antropologie en kan ons nie hier verder nagaan nie.

(iii) Dit is 'n hoogs twyfelagtige psigologie wat b.v. naasteliefde en godsdiens op neiginge wil terugvoer. Neiginge verstaan ek hier nie 'n ander sin as Heymans se definisie nie, nl. as die blywende aanleg in die geestesaard van die mens. Die hele kwessie van 'n blywende aard word b.v. in die volkekunde in 'n hoë mate betwyfel, nie alleen na die materiële kant nie maar ook na die formele. Al aanvaar ons 'n formele aard van die mens, word die inhoudelike in elk geval meegebring deur die kultuur waarin die individu leef. Die vraag is egter: Is hierdie inhoudelike 'n blywende aanleg of is dit 'n rangorde van waardevoorkeur?

Om op te som: Geen wilshandeling vind plaas sonder dat dit deur sy antesedente bepaal word nie. Hierdie antesedente is egter nie van dieselfde aard as die natuurkragte wat op fisiese gebied werksaam is nie, maar is (i) die situasie waarin die persoon verkeer, wat ons as bekend by die persoon moet veronderstel; (ii) die rangorde van waardes wat in die gemeenskap geld, wat aan die persoon bekend is, waarin hy insig het en wat ook vir hom geldig is, hom aanspreek met 'n behoorlikheidseis, en (iii) die persoon se besef van eie aanspreeklikheid, totrekenbaarheid en verantwoordelikheid. Die samehang tussen antesendente en gebeure is ook nie meganisties in enige sin van die woord nie. Wat 'n ondergeskikte faktor by Heymans is, naamlik die keuse en beslissing van die individu, is die kardinale punt, die archimediese punt. Die beslissing is nie net een punt in die reeks gebeurtenisse van die wilshandeling nie, maar is die punt waarvan die toerekenbaarheid van die persoon afhang. Ons moet liewer die kousaliteitseis vanuit hierdie punt besien as omgekeerd hierdie funt vanuit die kousaliteitseis. Die rangorde van waardevoorkeur hang ook nie uitsluitlik af van die soort persoon wat die voorkeur doen nie; as ons dit konsekwent deurvoer, kan ons by John Steinbeck se uitspraak uitkom: sedelikheid en onsedelikheid is bloot net 'n kwessie van swakkere of sterkere funksionering van bepaalde kliere. Hoewel ons die faktore van oorerwing, fisiologiese samestelling (o.a. Steinbeck se kliere) en so meer moet in aanmerking neem, is die aard van die individu vir my eerder afhanklik van die rangorde van waardevoorkeur, want dit is in die laaste instansie die grond van sy opvoeding sowel as sy selfgemaakte karakter.

5. Slotopmerkings.

Die problematiek van oorsaaklikheid en vryheid is eie aan die mo- 
derne filosofie, by uitstek die filosofie sedert Kant. Die Grieke ken ook die probleem, maar dit lê by hulle baie minder skerp as in die moderne tyd en die kousaliteitseis speel 'n baie geringer rol. Dit is iets tipies Grieks om 'n orde, reëlmaat, wetmatigheid en redelikheid (uitgedruk in die leer van die logos, die nots, ens.) in die natuur te aanvaar. Ten spyte van die sterk fatalistiese elemente wat ons later in die Hellenisme aantref, is die wetmatigheid van die natuur in elk geval tot diep in die Hellenistiese tyd eerder 'n redelikheid as ' $n$ blinde kousaliteit wat vreemd teenoor die mens staan. Feitlik sonder uitsondering aanvaar hulle die mens se vryheid en hierdie vryheid word in verband gebring met die redelikheid van die mens; die mens wat redelik handel, is vry, terwyl die een wat deur begeertes en emosies vasgevang is, onvry is (b.v. Plato, Stoisyne). Selfs waar ' $n$ determinisme in die natuutfilosofie aanvaar word, b.v. by die Stoisyne, word in die etiek nogtans die wilsvryheid voorgestaan; selfs die onderwerping aan die wêreldwet of wêreldrede, wat 'n belangrike rol in die Stoisynse etiek speel, is 'n vrye daad.

Met die opkoms van die Christendom kom daar nie 'n wesenlike verandering in die beskouing dat die redelike daad ' $n$ vrye daad is nie, maar die probleem verskuif in die mate dat die wilsvryheid 'n teologiese probleem word.

Saam met die opkoms van die natuurwetenskap aan die einde van die Renaissance kom ook die beskouing van die absolute determinisme op die voorgrond. Aanvanklik is die probleme wat hiermee saamhang dikwels nie raakgesien nie, soos ons by Priestley opmerk. Waar daarteen in opstand gekom is, was dit meestal met godsdienstige oorwegings in gedagte. Die enigste redding wat daar dikwels vir die vryheid gevind is, was in die een of ander vorm van dualisme, waarvan Descartes die bekendste voorbeeld is.

Vryheid was egter besig om 'n verlore stryd te stry. Selfs mense wat wilsvryheid gehandhaaf het, het dit gedoen in die terminologie van die wet van oorsaaklikheid; so b.v. Locke, Condillac, Hartley en andere. As voorbeeld kan ons Hume aanhaal; Vryheid is ,, a power of acting or not acting, according to the determination of the will."11

Im. Kant, op hierdie gebied net so 'n reusagtige figuur soos op die ander gebiede, het nog die beste daarin geslaag om vryheid werklik te red en dit te handhaaf, ten spyte van al die besware wat' $n$ mens teen sy formalisme, subjektivisme, twee-wêrelde teorie en so meet kan inbring. Maar ook Kant word geweldig geimponeer deur en werk teen die agtergrond van die natuurwetenskap. En Heymans, ten spyte van die geweldige erns wat hy van die etiese probleme maak, word ook deur die natuurwetenskaplike wêreldbeeld oorheers.

Want dit is wat intussen gebeur het en wat sy toppunt in die negentiende eeu bereik het: die determinisme, wat die werkhipotese van die

11) Inquiry VIII, Section 1. 
natuurwetenskap was, het 'n wêreldbeskouing geword. Waar die ontdekking van 'n natuurwetmatigheid die werkmetode van die ni tuurwetenskap was en die weg waarlangs metodes gevind is om die natuur te beheers, het dit ook die eis begin stel om geldig te wees in die verhouding van die mens tot sy medemens, tot sy God en tot homself. Die uiterste voorbeeld hiervan is die meganistiese materialisme. Die sciëntisme, die aanbidding van die natuurwetenskap, het as een van sy belangrike onderdele, miskien as sy ruggraat, die beskouing dat die mens een is en eensoortig is met die groot geheel van die natuur en dat wesenlik van hierdie natuur sy wetmatigheid is, waarvan ook kousaliteit 'n deel is.

Die problematiek van oorsaaklikheid en wilsvryheid is daarom m.i. vir 'n baie groot deel gebore uit 'n botsing van wêreldbeskouinge: aan die een kant is ons kinders van ons tyd en bewuste of onbewuste aanhangers van die sciëntisme; aan die ander kant het ons een van die mees primêre belewenisse van die mens, nl. ons eie vryheid en toerekenbaarheid. Tussen die twee deur moet ons so glad soos 'n paling probeer deurseil.

Dit is onder hierdie omstandighede dat die moderne gedagterigtings so interessant word. Die moderne indeterministiese beskouings in die fisika is nog baie jonk, skaars een geslag, en dit staan teen byna 'n duisend jaar se determinisme. Maar is dit nie moontlik dat hieruit 'n totaal ander wêreldbeskouing uiteindelik gebore sal word as die een wat tot nog toe gegeld het nie? En in die jongste tyd kry ons almeer figure in die wysbegeerte wat ten spyte van al die natuurgebondenheid van die mens bereid is om sy uniekheid en eiesoortigheid te verdedig, b.v. Theodor Litt, Erich Rothacker, Nic. Hartmann, Plessner, en so meer. Ten spyte van al die nausee waarmee die eksistensialisme my al meer vervul, mag ons hulle vormende effekte ook nie vergeet nie.

Ten slotte wil ek nog net daarop wys dat 'n groot deel van ons etiese besinning ook erfgoed is. As voorbeelde hiervan noem ek net die klemtoon op die rasionele, die kenning van die hele etiese situasie, die oorweging van moontlikhede, die wantroue teenoor die emosionele en die begerenswaardigheid van die beheersing van die mosies wat tipies van ons etiese besinning is en wat erfgoed van die Grieke is. ' $n$ Verdere voorbeeld wat ons kan noem, is die vooronderstelling van alle filosofiese etiek, naamlik dat mens wesenlik goed is, in staat is om uit sigself die goeie te ken en te doen. Sedert Sokrates het dit nog nooit verander nie. Die enigste filosoof wat nog erns van ,,das radikal Böse" gemaak het, was Kant, en hy het dit soos 'n warm patat gelos, omdat dit geblyk het 'n onverteerbare „Fremdkörper" vir die filosofie te wees.

Ek is bevrees, mnr. die Voorsitter, dat ek op 'n taamlik negatiewe noot eindig. Ek het vir $u$ die probleem gestel en 'n paar oplossings as voorbeelde aangebied, maar so ver dit my betref, net meer probleme gevind. So hoort dit miskien in die filosofie.

Die sciëntisme is een van my sondebokke waatop ek 'n groot deel 
van ons Westerse kultuurpenarie wil laai. Daarom wil ek ook die terminologie van die sciëntisme vermy en verkies om te sê: Geen wilshandeling is redeloos of grondeloos nie, om sodoende die term oorsaak te vermy. Egter, oorsaaklik bepaald of oorsaakloos, redeloos of gegrond, gedetermineerd of absoluut vry, primêr is ek bewus van my skuld en my toerekenbaarheid en verantwoordelikheid vir daardie skuld. Daarom is my sedelikheid nog altyd vir my 'n groter probleem as my etiek.
P. S. DreYer, 